\title{
LIVABILITY THEORY
}

Ruut Veenhoven

In: Alex C. Michalos (Ed.) Encyclopedia of Quality of Life and Well-Being Research Springer, Dordrecht, Netherlands, 2014. Springer Reference Series, pp. 3645-3647. ISBN 978-94-007-0752-8

DOI: 10.1007/978-94-007-0753-5_1669

\section{SYNONYMS}

Habitability; Person-environment fit

\section{DEFINITION}

Livability is the degree to which a living environment fits the adaptive repertoire of a species. Applied to human society, it denotes the fit of institutional arrangements with human needs and capacities. Livability theory explains observed differences in happiness in terms of need- environment fit.

\section{DESCRIPTION}

\subsection{Assumptions}

Livability theory involves the following six key assumptions:

1. Like all animals, humans have innate needs, such as for food, safety, and companionship.

2. Gratification of needs manifests in hedonic experience.

3. Hedonic experience determines how much we like the life we live (happiness). Hence, happiness depends on need gratification.

4. Need gratification depends on both external living conditions and inner abilities to use these. Hence, bad living conditions will reduce happiness, in particular when its demands exceed human capabilities.

5. Societies are systems for meeting human needs, but not all societies do that job equally well. Consequently, people are not equally happy in all societies.

6. Improvement of the fit between social institutions and human needs will result in greater happiness. 
A first formulation of this theory is found in Veenhoven (1993), and later elaborations can be found in Veenhoven and Erhardt (1995), Veenhoven and Ouweneel (1995), and Veenhoven (2000, 2010a).

\subsection{Contrary Theories of Happiness}

Other views on happiness are less optimistic about the chance of improving the human lot. One perspective centers on a family of theories that see happiness as the result of cognitive comparison, while another set sees happiness as a stable "trait" rather than as a variable "state."

\section{Comparison Theories}

These theories assume that happiness results from comparisons between notions of how life should be and how it actually is. The greater the gap between what one wants and what one has, the less happy one is (Michalos, 1985). In this theory, "wants" differ from the above mentioned "needs." Firstly, wants are held consciously, while one may be unconscious of what one needs. Secondly, wants are social constructs and as such likely to vary across cultures, while needs are hardwired and universal. Thirdly, wants tend to be endless, while needs can be satisfied. This latter point implies that great happiness is not possible. If we always want more than we have, we will never get any happier. It is for this reason that the pursuit of happiness has been typified as a "hedonic treadmill" (Brickman \& Campbell, 1971). Variants of this theory emphasize different standard of comparison and different mechanisms that inflate aspirations. See the lemma on "contentment" in this encyclopedia.

\section{Trait Theories}

These theories hold that happiness is a static characteristic of an individual, comparable to the color of one's hair. One variant claims that happiness is largely genetic, some people are born to be happy, and others to be constitutionally depressive (e.g., Lykken, 1999). Another variant is that our early experiences program us to enjoy life or not. Cummins' (1995) set-point theory assumes that we are all hardwired to feel reasonably happy (between 7 and 8 on scale $0-10$ ) and that homeostatic mechanisms keep us around that level, unless extreme circumstances push us below or above.

\subsection{Evidence}

Since we cannot yet look in people's heads, we cannot test these competing theories as such. Yet we can check some of their implications. One implication of both comparison theory and trait theory is that average happiness will be about the same all globally. This is clearly not the case, average happiness on a scale $0-10$ is 2,8 in Togo and 8,2 in Denmark (Veenhoven, 2012a). Another implication is that average happiness will remain at the same level, even if living conditions deteriorate or improve in a nation. This appears not to be the case either. Average happiness dropped dramatically in Russia after the Ruble crisis in the late 1990s, and in the 1990s, happiness also dropped in other postcommunist countries where major 
transformations took place. Yet average happiness has gone up in most developed countries over the last 30 years, and in the last 10 years, it has also increased in the postcommunist countries (Veenhoven, 2012b). Both the differences in average happiness across nations and the rise of happiness over time correspond with social qualities, such as economic development, political democracy, and good governance.

Follow-up studies at the individual level also show considerable changes in happiness over time, which are linked to both things that happen in our lives, such as marriage and bereavement (Headey, 2006).

Still another piece of evidence is that conditions for happiness appear to be fairly universal. Though there is some variation in what people think will make them happy, actual correlates of happiness are strikingly similar all over the world (Veenhoven, 2010b).

All this fits livability theory quite well.

\subsection{Political Relevance}

The theoretical differences in happiness discussed here are no mere academic hairsplitting. If livability theory is wrong, there is no point in trying to create greater happiness for a greater number of citizens. So far, the data shows that this theory is right; hence, creating greater happiness still qualifies as a political goal. 


\section{REFERENCES}

Brickman, P., \& Campbell, D. T. (1971)

Hedonic relativism and planning the good society.

In M. H. Appley (Ed.), Adaptation level theory.

New York: Academic.

Cummins, R. A. (1995)

On the trait of the gold standard for subjective well-being.

Social Indicators Research, 35, 179-200.

Headey, B. (2006)

Happiness: Revising set point theory and dynamic equilibrium theory to account for

long term change.

DIW discussion paper 607.

Berlin, Germany.

Lykken, D. T. (1999)

Happiness: What studies on twins show us about nature, nurture and the happiness set-point.

New York: Golden Books.

Michalos, A. C. (1985)

Multiple Discrepancies Theory (MDT)

Social Indicators Research, 16, 347-413.

Veenhoven, R. (1993)

Assessing livability of nations by happiness. Part I in happiness in nations':

Subjective appreciation of life in 56 nations 1946-1992.

RISBO, Studies in Sociale en Culturele Verandering, nr. 2, p. 364, Erasmus

University Rotterdam, ISBN 90-72597-46.

Veenhoven, R. (2000)

The four qualities of life. Ordering concepts and measures of the good life

Journal of Happiness Studies, 1, 1-39.

Veenhoven, R. (2010a)

Life is getting better: Societal evolution and fit with human nature.

Social Indicators Research, 97, 105-122. 
Veenhoven, R. (2010b)

How universal is happiness?

In E. Diener, J. F. Helliwell, \& D. Kahneman (Eds.), International differences in well-being, 2010 (pp. 328-350).

New York: Oxford University Press. Chapter 11, ISBN-13: 978-0-19-973273-9.

Veenhoven, R. (2012a)

Average happiness in nations.

World Database of Happiness, Erasmus University Rotterdam.

Veenhoven, R. (2012b)

Trends in average happiness in nations

World Database of Happiness, Erasmus University Rotterdam.

Veenhoven, R., \& Erhardt, J. (1995)

The cross-national pattern of happiness: Test of predictions implied in three theories of happiness.

Social Indicators Research, 34, 33-68.

Veenhoven, R., \& Ouweneel, P. (1995).

Livability of the welfare-state: Appreciation-of-life and length-of-life in nations varying in state-welfare-effort.

Social Indicators Research, 36, 1-49.

\section{Cross-References in Encyclopedia:}

Happiness

Need Theory 